\title{
VOCATIONAL INTEREST, ATTRIBUTION AND CAREER MATURITY AMONG SECONDARY SCHOOL TEACHERS IN SOKOTO METROPOLIS
}

\author{
Dr. M. U. TAMBUWAL AND SHEHU YAHAYA TSAGEM,
}

\begin{abstract}
The main thrust of this study was to examine and imvestigate whether relationships exist among vocational interest, atribution and career maturity among teachers in secondary schools of Sokoto state. Some research questions raised were: Is there any relationship between vocational interest and career maturity of secondary school teachers in Sokoro state; and is there any relationship between vocational interest and attribution of secondary school teachers in Sokoto state? Some mull hypotheses generated for the conduct of the studv were that: there is no significant relationship between vocational interest and career maturity of secondary school teachers in Sokoto state and there is no significant relationship between vocational interest and attribution of secondary school teachers in Sokoto state. The study used the correlational survey methodology for 2.37 subjects drann from the total population by means of simple random sampling technique. Data for the study was collected with the use of an adopted version of Bakare's Vocational Interest Inventory, an adopted version of Olomolaiye's Self Other Motivation Scale and an adopted version of Crites' Career Maturity Inventory Attitude Scale. Some major findings of the study were that there is relationship between vocational interest and career maturity and also that there is relationship between career maturity of secondary school teachers in Sokoto state. Some of the recommendations made were that the Ministry of Education in Sokoto state and the teachers themselves should embark on developing both internal and extenal inspiring factors toward the general development of the teachers' career maturity thus leading to sinund academic effectiveness and that the state Ministry of Education should look for all possible ways to develop teachers' interest and attribution which will eventually enhance the realization of positive and efficient self-esteem, self-efficacy, self-concept and self fulfillment which are necessary ingredients in career maturity etc.
\end{abstract}

\section{Introduction}

Interest is the most important gearing factor in the establishment and development of any aspect of human endeavor. This is because it is a phenomenon that leads individual person to choose, pursue and develop a certain aspect of his/her life. Colman (2003) emphasized that interest is a state of mind which posits liking and disliking on certain issues. Therefore, vocational interest can be seen as a process of making a preference to embark on certain vocation for the purpose of shaping. individual's personality. It is also a state of mind that established individual's preference for certain work activity.

Therefore, that is why vocational interest is the most important facet of an individual's life that explained why it is probably the most dominant single and effective influence in the course of his life. This is because the vocation affects individual family structure, personality, economic status, social and intellectual activities as well as one's psychological disposition (Sambo, 2098).

Because so many variables revolve around the establishment and development of individual's vocation. among which ane fnetest attribution as

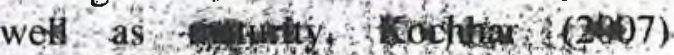


explained that individual and group started developing interest in choosing a certain vocation leading to the attainment of maturity through attributing that interest with some variables. Therefore, one can understand that vocational interests do not appear all of a sudden, but it goes hand in hand with the general personality development of an individual. As such. every individual is expected to have exclusive interest on certain vocation or job. More so. the development of the interest could be attributed to internal or external causes based on one's personal development trend. Once the interest is developed, vocational choice which is the fundamental factor in achieving happiness and satisfaction in life could be at hand (Shertzer and Stone as cited in Tambuwal, 2001).

Tambuwal (2001) clarified that vocational adjustment of an individual should consist of personal as well as environmental competence. Therefore, one can understand that people have every ability and opportunity to make wise career choice for their lives.

In line with the above statement, one can understand that vocational interest is a longitudinal aspect of individual's personality development. That is to say a person needs to understand and appreciate career prospects before developing any interest. And apparently in the course of developing vocational interest one may link the development with certain cause thereby attributing his/her . career establishment and development to certain internal or external consequences.

Many studies conducted indicated that vocational interest influence career maturity of an individual as seen in those of Almiskry, Bakar and Mohammed (2009), Popa and Butnaru (2008), Rama (2000) and Mehta, Bajaj and Kumar (2006). The findings showed significant relationships between vocational interest and career maturity.

Other studies also explained that attribution directly influence vocational interest of an individual (Magaji, 2010). Another work also established a significant relationship between vocational aspiration of senior secondary schools students and their external attribution of their parents (Abubakar, 2010).

Some studies also clarified that there is a significant relationship between how individual person explains his action in relation to his career maturity and the actual processes followed in attaining career maturity of the person (Abdullahi, 2001). In essence, the way an individual developed and matured depends solely on the explanation of how things are happening in that person. This is in line with what Sandra (1992) and Carim, Basson and Coetzee (2006) believed.

\section{Statement of the Problem}

It is very clear that interest is seen as the most important factor in the attainment of certain goal and that is why this study is interested in studying vocational interest of teachers thereby linking it with their attribution of success, adjustment and decision making in terms of career life. In the area of study, it is common to encounter teachers that are totally disillusioned with their jobs. They have reached a level that they don't have any more interest in their jobs; hence, their performance is very low. So also is 
their perception and belief about how success is really achieved. Thus, the main thrust of this study was to examine and investigate whether relationships exist among vocational interest, attribution and career maturity among teachers in secondary schools of Sokoto state.

\section{Met̂hodology}

The study used the correlational survey methodology. Measures of vocational interest and attribution are the predictor or independent variables while the measure of career maturity is the dependent variable. The population of this research was the entire 392senior secondary school teachers within Sokoto metropolis(Department of Planning and Statistics, Ministry of Education, Sokoto state, 2012). However, two hundred and thirty-seven (237) subjects were drawn from the total population by means of simple random sampling technique. This constructs a $95 \%$ confidence interval with a Margin of Error of about $\pm 4.0 \%$ (http://research-advisors.com/, 2006). Level of Significance was at 0.05 .

\section{Instrumentation}

The following instruments were employed to collect data in this study:

- Adopted version of Bakare's (1977) Vocational Interest Inventory was used to measure the teachers' vocational interest. A revalidation of the instrument's content validity was established and documented in studies by Tambuwal (2001) and Idris (2010). Reliability indices of 0.78 and 0.74 were also realized and established in the same studies by Tambuwal (2001) and Idris (2010) respectively.
- Adopted version of Olomolaiye's (1986) Self Other Motivation Scale that measured the teachers' attribution. A revalidation of the instrument's content validity was established and documented in a study by Tambuwal (2001). Reliability index of 0.88 was also realized and established in the same study by Tambuwal (2001).

- Adopted version of Crites' (1973) Career Maturity Inventory Attitude Scale that measured teachers' career maturity. A revalidation of the instrument's content validity was established and documented in a study by Tambuwal (2001). Reliability index of 0.72 was also realized and established in the same study by Tambuwal (2001).

\section{Research Questions}

The following research questions were used to guide the study.

- Is there any relationship between vocational interest and career maturity of secondary school teachers in Sokoto state?

- Is there any relationship between vocational interest and attribution of secondary school teachers in Sokoto state?

- Is there any relationship between attribution and career maturity of secondary school teachers in Sokoto state?

\section{Hypotheses}

The following null hypotheses were generated in the conduct of the study.

$\mathrm{HO}$ I: There is no significant relationship between vocational interest and career maturity of secondary 
school teachers in Sokoto state.

$\mathrm{HO}_{2}$ There is no significant relationship between vocational interest and attribution of secondary school teachers in Sokoto state.

$\mathrm{HO}_{3:}$ There is no significant relationship between attribution and career maturity of secondary school teachers in Sokoto state.

Analyses and Interpretation of Results

Table 1: Relationship between Vocational Interest and Career Maturity of Secondary School Teachers in Sokoto state.

\begin{tabular}{lcclllll}
\hline Variables & $\mathrm{N}$ & Mean & $\begin{array}{l}\text { Std. } \\
\text { Deviation }\end{array}$ & Df & r-Cal & $p$-Value & Decision \\
\hline Vocational Interest & 237 & 77.74 & 21.687 & 235 & 0.371 & 0.095 & Sig. \\
\cline { 1 - 4 } Career Maturity & 237 & 81.33 & 17.102 & 235 & & \\
\hline
\end{tabular}

From table 1 above it can be seen that the relationship between vocational interest and career maturity result is higher. This is because of the calculated r-value of .371 at .05 level of confidence, using 235 degrees of freedom as against the p-value of .095 . This indicates that there is relationship between vocational interest and career maturity. Therefore, the hypothesis which states there is no significant relationship between vocational interest and career maturity is not accepted. Thus, this adequately answer research question 1 and it was concluded that there is relationship between vocational interest and career maturity of secondary school teachers in Sokoto state.

Table 2: $\quad$ Relationship between Attitude Vocational Interest and Attribution of Secondary School Teachers in Sokoto state.

\begin{tabular}{llllllll}
\hline Variables & $\mathrm{N}$ & Mean & $\begin{array}{l}\text { Std. } \\
\text { Deviation }\end{array}$ & Df & r-Cal & $p$-Value & $\begin{array}{l}\text { Decisio } \\
\mathrm{n}\end{array}$ \\
\hline Vocational Interest & 237 & 77.74 & 21.687 & 235 & 0.480 & 0.095 & Sig. \\
\hline Attribution & 237 & 53.36 & 22.032 & 235 & & \\
\hline
\end{tabular}

From table 2 above it can be seen that the relationship between vocational interest and attribution result in a higher calculated r-value of 0.480 at 0.05 level of confidence, using 235 degrees of freedom as against the p-value of 0.095 . This indicates that there is relationship between vocational interest and attribution. Therefore, the hypothesis which states there is no significant relationship between vocational interest and attribution is not accepted. Thus, this adequately answer research question 2 and it was concluded that there is relationship between vocational interest and attribution of secondary school teachers in Sokoto state. 
Table 3: Relationship between Attribution and Career Maturity of Secondary Scl ool Teachers in Sokoto state.

\begin{tabular}{lcclcccc}
\hline Variables & N & Mean & $\begin{array}{l}\text { Std. } \\
\text { Deviation }\end{array}$ & Df & r-Cal & $p$-Value & Decision \\
\hline Attribution & 237 & 53.36 & 22.032 & 235 & 0.660 & 0.095 & Sig. \\
\hline Career Maturity & 237 & 81.33 & 17.102 & & & \\
\hline
\end{tabular}

From table 3 above it can be seen that the relationship between attribution and career maturity result in a higher calculated r-value of 0.660 at 0.05 level of confidence, using 235 degrees of freedom as against the p-value of 0.095 . This indicates that there is relationship between attribution and career maturity. Therefore, the hypothesis which states there is no significant relationship between attribution and career maturity is not accepted. Thus, this adequately answer research question 3 and it was concluded that there is relationship between attribution and career maturity of secondary school teachers in Sokoto state.

\section{Discussion of the Findings}

Finding of this study reveals that there is relationship between vocational interest and career maturity of secondary school teachers in Sokoto state. This maintains the stand of Popa and Butnaru (2008), Rama (2000), Patton and Creed (2001) that revealed positive relationship between vocational interest and career maturity of individuals. Therefore, this study adds to earlier findings that developing teachers' interest and abilities will certainly determine their success in their vocational development thereby resulting to full maturity in their career endeavors. Okon (2001) uphold this finding by explaining that personality intervention programmes assist individual in the development of interest resulting to job satisfaction which is the peak of career maturity.

Finding of this study also reveals that there is relationship between vocational interest and attribution of secondary school teachers in Sokoto state. This is accorded with the findings of Tambuwal (2001), Popa and Butnaru (2008) and Magaji (2010) whose studies established positive relationship between individual's vocational interest and attribution. This study contributes and supports Tambuwal's (2001) view that to build individual's interest, one needs to ascertain some innovative factors. These measures can be used to develop the interest of teachers in secondary schools in Sokoto state through such factors as on the general development of the individual as well as the development of the place of work.

Another finding of the study reveals that there is relationship between attribution and career maturity of secondary school teachers in Sokoto state. This result is in support of the findings by Abdullahi (2001), Wu (1998), Walker and Sorce (2009), Manuele (1984), Millet (2005) and Sandra (1992) that revealed significant relationships between attribution and career maturity. This result is also in line with the finding of Patton, Butnaru and Creed (2004) which reaffirmed that individuals with internal attribution tend to display maturity in decision making in terms of career 
development. The finding of this study is also in support of Tambuwal (2001) who upheld that persons with internal attribution perceived all development positively. Therefore the result implies that to enhance career development of teachers in secondary schools in Sokoto state, one needs to develop their personality through various techniques in order to motivate them internally and externally.

\section{Conclusion}

From the findings and discussion of the results, it was concluded that there is relationship between vocational interest and career maturity; there is relationship between attribution and career maturity and also there is relationship between vocational interest and attribution of secondary school teachers in Sokoto state.

\section{Implications and Recommendations}

The results of the study revealed that teachers' vocational interest, attribution and career maturity are intricately interwoven, thus the authorities concerned should make the necessary adjustment to boost the effectiveness of the teachers in their careers by providing physical, psychological, social as well as educational settings that could assist in enhancing their adjustment in self and in their places of work. Psychologically, socially and economically the teachers should be reinforced to develop interest in their career as well as interact positively with one another in their respective places of work. Considering these, the following recommendations are suggested:
- The Ministry of Education in Sokoto state and the teachers themselves should embark on developing both internal and external inspiring factors towards the general development of the teachers' career maturity thus leading to sound academic effectiveness.

- The state Ministry of Education should look for all possible ways to develop teachers' interest and attribution which will eventually enhance the realization of positive and efficient self-esteem, selfefficacy, self-concept and self fulfillment which are necessary ingredients in career maturity.

- The ministry should raise the teachers' interest and morale by practically employing measures like the regular settlement of all entitlements, following due process in promotions, frequent and regular refresher courses and seminars or workshops and positive recognition and rewarding of outstanding performances. Also the state Ministry of Education should establish functional counselling centers, which will cater for the needs of the teachers too, in all the secondary schools in the state. This will assist in finding lasting solutions to some difficulties faced by some of the teachers.

\section{References}

Abdullahi, O. E. (2001). Relationship among achievement motivation, self-esteem, locus of control and academic performance of Nigerian university students. A paper presented at the department of 
Educational Foundation, University of Ilorin.

Abubakar, B. (2010). Relationship among socio-economic status, gender, self-concept and vocational aspiration of senior secondary school students in Sokoto. An unpublished M. Ed Dissertation submitted to the Department of Educational Foundations, Usmanu Danfodiyo University, Sokoto - Nigeria.

Almiskry, A. S., Bakar, A. R. \& Mohammed, O. (2009). Gender difference and career interest among undergraduates: Implication for career choice. European Journal of Scientific Research, 12 (10): 132-157.

Carim, N., Basson, J.\& Coetzee, M. (2006).The relationship between job satisfaction and locus of control in South Africa Call Center Environment. South Africa Journal of Labour, 30 (2): 45-59.

Colman, A. M. (2003). Oxford dictionary of psychology. New York: Oxford University Press.

Idris, F. (2010).Relationship between self-esteem and occupational choice of students of secondary schools in Birnin Kebbi Metropolis of Kebbi State. An unpublished M. Ed Dissertation submitted to the Department of Educational Foundations, Usmanu Danfodiyo University, Sokoto - Nigeria.

Kochhar, S. K. (2007). Guidance and counselling in colleges and universities. New Delhi: Sterling Publishers Private Ltd.
Magaji, S. H. (2010). Relationship among locus of control, personality and academic achievement of secondary school students in Sokoto Metropolis. Unpublished M. Ed Dissertation submitted to the Department of Educational Foundations, Usmanu Danfodiyo University, Sokoto - Nigeria.

Manuele, C. (1984). Modifying vocational maturity in adults with delayed career development. Vocational Guidance Quarterly, 34 (2): 102-122.

Mehta, M., Bajaj, S.\& Kumar, V. V. (2006).Effect of Personality Intervention and Career Intervention Programmes on Vocational Indecision among adolescent boys. Journal of Indian Educational Review, 42 (2): 92 117.

Millet, P. (2005). Locus of control and its relation to working life: studies from the field vocational rehabilitation small firms in Sweden. Unpublished PhD Thesis, Luka University of Technology Sweden.

Patton, W. \& Creed, P. A. (2001). Development issues in career maturity and career decision status. Joumal of Career Development, 25 (2): 74-89.

Popa, N. L. \& Butnaru, S. (July, 2008). Attributional style and prevailing vocational orientations among university student in humanities. $4^{\text {th }}$ International Conference on Educational Technology, Bucharest - Romania. 
Rama, M. B. V. (2000). The relationship between job satisfaction and life satisfaction among secondary school teachers. Journal of Educational Research and Extension, 37(2): 45-61.

Sambo,S. (2008).Understanding guidance and counselling. Zaria: Ahmadu Bello University Press.

Sandra, K. (1992). Life cycle and career development. Adult Learning and Vocational Education Digest, 119(2): 113-127.

Tambuwal, M. U. (2001).Relationships among self-concept, self-other motivation and career maturity of teachers in tertiary institutions in Sokoto state. An Unpublished Ph. D. Thesis submitted to the Department of Education, Usmanu Danfodiyo University Sokoto - Nigeria.

Walker, A. S. \& Sorce, P. A. (2009).Correlates of job satisfaction of early and career employees in printing and publishing companies. New York: Printing Industry Center.

Wu, W. T. (October, 1998). Vocational interest and career maturity of male high school students talented in Math and Science. Paper Presented at $45^{\text {th }}$ Annual Convention of National Association of Gifted Children, Louisville - U. S. A. 